\title{
Floristic Composition of Home-garden Systems in Dumbara (Knuckles) Conservation Area with an emphasis on Endemic Species
}

\author{
D. M. A. J. Dissanayake and P. L. Hettiarachchi ${ }^{*}$ \\ Faculty of Applied Sciences, Rajarata University of Sri Lanka \\ Date Received: 24-11-2012 Date Accepted: 18-02-2013
}

\begin{abstract}
Home gardens are multistoried ecosystems and are important not only for in-situ biodiversity conservation, but also as valuable food sources, fodder, medicine and spices. The main objective of this study was to make decisions about the variations of home garden composition and to identify the endemic species. Fifty five home gardens were studied in northern flank from January to April 2012. Two large $\left(10 \times 10 \mathrm{~m}^{2}\right)$ and four small $\left(1 \times 1 \mathrm{~m}^{2}\right)$ quadrates were studied in each home garden. Individuals $\geq 1.5 \mathrm{~m}$ height and $\geq 1 \mathrm{~cm}$ DBH were measured to calculate IVI. Species identification was done on site and further at the National Herbarium, Peradeniya. Total of 1335 individual woody-perennials and 4603 herbs were found in $11,000 \mathrm{~m}^{2}$ of study area. One hundred and fifty two woody-perennial species (19 endemic, 44 naturalized exotics, 37 cultivated and 52 timber) under 54 families and 56 herb species (46 medicinal) belonging to 33 families were recorded. Euphorbiaceae was the dominant family with 15 species, followed by Fabaceae (11 species), Anacardiaceae (10 species), Rutaceae (10 species), Myrtaceae (7 species), Rubiaceae (6 species), Arecaceae (6 species), Moraceae (5 species), Sapindaceae (4 species) and Zingiberaceae (4 species). Highest number of plant families (43) was recorded in Pitawala, while the lowest number of plant families was recorded in Polommana (24). Based on the Importance Value Index (IVI), the species to pay highest priority for conservation were selected. According to Shannon diversity values for different villages, Rathninda is the most stable and less disturbed, whereas Polommana is the most unstable and highly disturbed village. There were five endemic Anacardiaceae species (Campnosperma zeylanicum, Mangifera zeylanica, Semecarpus coriaceae, Semecarpus nigro-viridis, Semecarpus walkeri). Twelve percent of the studied population were interested in timber trees such as Tectona grandis, Melia azedarach, Swietenia macrophylla and Chloroxylon swietenia. Twelve percent of the studied population preferred fruit trees while 5\% were interested in some medicinal plants. Preference of this nature indicates that in the future, the plant diversity in these home gardens is likely to decline considerably. This might even lead to the extinction of rare, endemic plant species. Therefore, people in northern flank encouraged to incorporate multipurpose endemic plants and plants with less IVI values in their home gardens in order to maintain high diversity and to conserve endemic and relatively rare plants while gaining substantial income through their home gardens.
\end{abstract}

Keywords: Northern Flank, Home gardens, Conservation, Woody-perennials, Endemic species

\section{Introduction}

Tropical home gardens are generally regarded as sustainable production systems (Abdoellah et al. 2001). A home garden is a clearly bounded piece of land cultivated with a diverse mixture of annual and perennial crops, and on which a house is built (Karyono, 1990). The major function of home gardens especially in rural areas, are subsistence production and income generation (Soemarwoto and Conway, 1992). Because of the high biodiversity existing in home gardens, a wide spectrum of multiple-use products can be generated with relatively low labour, cash or other inputs (Christanty, 1990).

*Correspondence: phlakshmi@yahoo.com

Tel: $+94712448139,+94771238980$

ISSN 2235-9370 Print / ISSN 2235-9362 Online C2013 University of Sri Jayewardenepura

24 
In times or seasons of scarcity, home gardens with their diverse products available year-round, contribute to food security. They also fulfil many social, cultural and ecological functions (Abdoellah et al., 2001). The multi-layered, forest-like vegetation structure of home gardens contributes substantially to the sustainability of this production system. Among others, this structure can protect the soil from erosion, offers a habitat to wild plants and animals, promotes a favourable microclimate and makes efficient use of light, water and other resources (Christanty et al., 1986). Because of their large crop species and varietal diversity, home gardens are regarded as an ideal production system for in situ conservation of genetic resources (Watson and Eyzaguirre, 2002). However garden diversity varies according to ecological or socio-economic factors or characteristics of gardens or gardeners (Christanty et al., 1986).

Home gardens particularly preserve much of the cultural history, as they are the sites where many useful plant species have been subjected to intense management regimes over extended periods. Through many years, farmers have cultivated and selected the plant species they desired, and in this way, home gardens are reservoirs of current and potential resources as well as a crucial site of selection and domestication of some plant species (Hawks, 1983)

Plant composition in home gardens is possibly influenced by factors like: access to water, economic activities of owners and availability of labour, traditional social organization, modernization processes and economic development (Rico-Grey et al., 1990). Using multivariate statistical techniques, researchers have found that floristic composition of home gardens was relatively similar within villages, but varied among regions.

The home gardeners are perpetual experimenters, and they are constantly trying and testing new species, varieties and management over the centuries they have selected specific species and manipulated their physical and ecological locations, planting for maximising space and production. From the ground layer to upper canopy, the gradient of light and humidity determine different niches that species exploit according to their own requirements (Fernandes and Nair, 1986). Therefore study of these parameters gives an idea of the temporal and spatial positioning of plants, species interaction and mixed species silviculture that are pertinent for designing multistate agro forestry and for the management of its productivity (Gillespie et al., 1993).

Dumbara range is very important in terms of its hydrological wealth as the catchment of Sri Lanka's longest river, the Mahaweli. The range is endowed with many different forest types. A total of 1033 flowering plants belonging to 141 families have been recorded from the diversified vegetation types in Dumbara. Among them, 255 (25\%) are tree species, while the balance consists of shrubs or herbs, Of the total number of flowering plant species documented in Dumbara, $15 \%$ are endemic to Sri Lanka, while about 3\% are nationally threatened. Although the Dumbara area covers less than $0.5 \%$ of the land in the country, it contains almost one third of the island's flowering plant species (Diversity of woody plants in the Dumbara forest, Environment Management Division - Forest department, 2005).

Home gardens similar to natural forests are found around the homesteads of Dumbara area. A well-developed multi-storey home garden generally includes a canopy $(20 \mathrm{~m})$, sub canopy (10 m) and shrub/ herb layer. Home gardens are also important faunal habitats that provide animals with feeding and nesting grounds. There are around 80 villages in and around the Dumbara forest region which form a unique bio cultural landscape. Even in this sophisticated era, life in these villages exhibit the simple harmonious co-existence of man and nature.

Information on the studies carried out in home garden in the northern flank of Dumbara is scares. This study was carried out in some peripheral villages of the Northern Flank of Dumbara home gardens to examine component interactions and productivity in the home gardens. Information on only two related studies namely "Conservation implications of home garden agro-forestry systems", and "Livelihood Development" carried out by DGAPIK Abeywardana, (University of Peradeniya) in 2008 is available. However, those only provide information on 3 villages; Kalugala, Kosdanda and Udailluka in Dumbara South-Eastern Flank. Hence, this study is important to compare the results of 
above two Flanks and to make decisions about the variations of home garden composition in Dumbara. This study was designed to accomplish following objectives;

- To identify floristic composition of home garden systems in some peripheral villages of Dumbara (Knuckles) Conservation Area.

- To identify the endemics, naturalized exotics and timber trees in the study area

- To identify plant species and highly disturbed villages for conservation

\section{Methodology}

\subsection{Study area}

Dumbara conservation forest nestles within the Dumbara Mountain Range - Sri Lanka's misty mountains. Located at latitudes $705^{\prime} \mathrm{N}$ and longitudes $810^{\prime} \mathrm{E}$ and covering $180 \mathrm{~km}^{2}$, its situated at the boundary of the wet and dry zones. The study area of the research lies in several peripheral villages of the Knuckles Conservation area, located in Matale district. Geographical coordinates are $7^{\circ} 17^{\prime}$ to $7^{\circ}$ $40^{\prime}$ North and $80^{\circ} 43^{\prime}$ to $80^{\circ} 55^{\prime}$ East. This covers areas including human habitations, well wooded home gardens, Paddy fields and forest patches. The study area is situated within the wet zone of Sri Lanka.
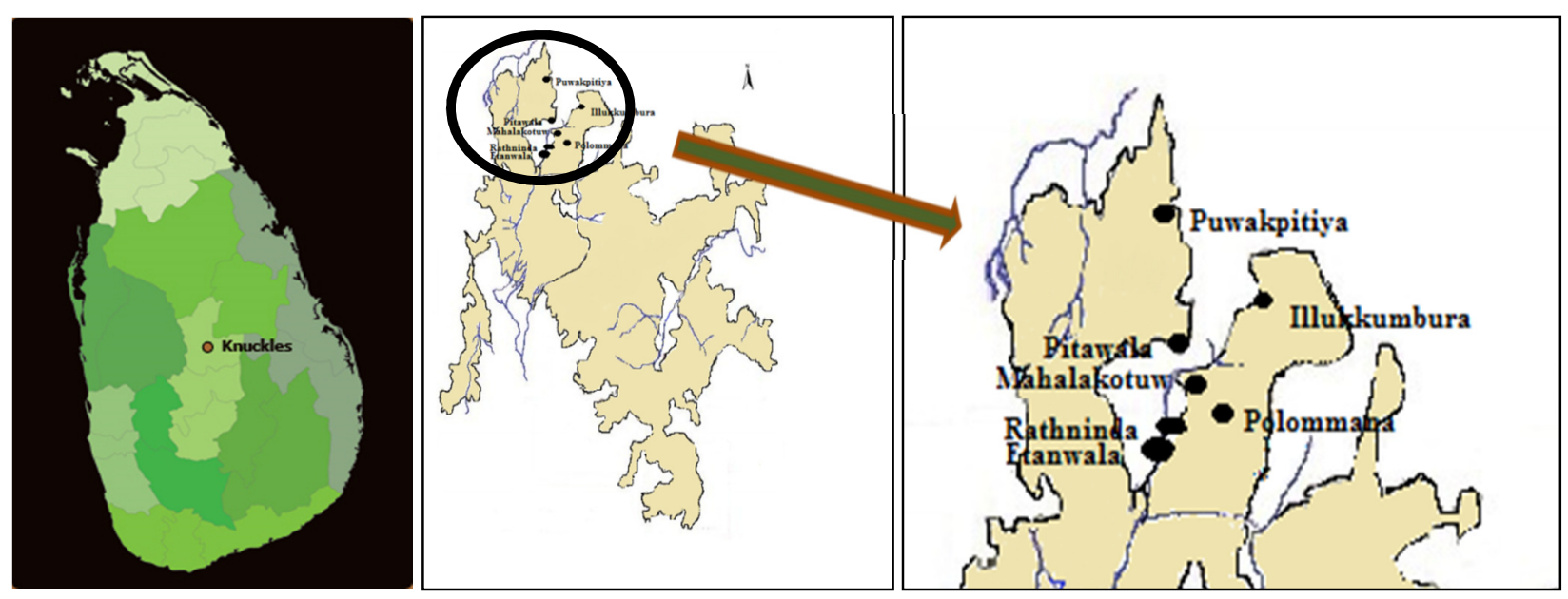

Figure 1: Detailed map of the study site

To conduct the study, six villages (Pitawala, Polommana, Atanwala, Rathninda, Mahala Kotuwa and Illukkumbura) from the northern flank (within Matale District) of Dumbara Conservation Area were selected in January 2012 considering some factors such as elevation and distance from the existing natural or semi-natural forests. Five (5) home gardens from Polommana village (because there were only five homes) and ten (10) home gardens from other 5 villages were selected. To study the structure and composition of the home garden vegetation, the following methods were applied:

a.) Woody vegetation: Two large $(10 \mathrm{~m} \times 10 \mathrm{~m})$ quadrates were studied from each home garden selected. All the individuals above $1.5 \mathrm{~m}$ height and above $1 \mathrm{~cm}$ DBH were identified into species level, counted and recorded the number of individuals, DBH and height were measured. To quantify and compare the species dominance within home gardens in each village, Density, Frequency, Dominance, basal area and Importance Value Index (IVI) were calculated for the species.

b.) Herbaceous (ground layer) vegetation: Two small ( $1 \mathrm{~m} \mathrm{x} 1 \mathrm{~m})$ quadrates were studied from each large quadrate selected (Four quadrates for each home garden). All individuals were identified into their species level, counted and recorded. 


\subsection{Identification of plant species}

Onsite identification was done for the common species using the expert and indigenous knowledge. They were identified up to species level using the checklist. Determination of other species was done with the help of National Herbarium, Peradeniya.

Structured and informal interviews were conducted when necessary (depending on the literacy level of the household). Additionally, the traditional practices and rituals related to forest-home garden activities and use of indigenous knowledge on wellbeing of the system were taken into surveying.

\subsection{Data Analysis}

1. Shannon-Weiner index: Species diversity of the plants recorded in quadrates was analyzed with the use of Shannon-Weiner index.

$$
\begin{aligned}
H=-\sum_{i=1}\left(p_{i}\right)\left(\log p_{i}\right) & \\
& H=\text { Shannon- Weiner index } \\
& S=\text { Number of Species } \\
& P_{i}=\text { Population of total sample belonging to the } i^{\text {th }} \text { Species }
\end{aligned}
$$

2. Density, frequency and dominance were calculated for IVI (Importance Value Index)

3. Bio-Diversity professional version 2.0 was used to analyse distribution, Simpson Diversity index and Margalef Diversity index.

\subsection{Data Analyzing Techniques}

\section{Abundance}

$$
\begin{aligned}
& \text { Relative Frequency }=\frac{\text { Number of sample plots with a sighting of a species }}{\text { Total number of sample plots }} \times 100 \\
& \text { Relative Density }=\frac{\frac{\text { Number of individuals of a species }}{\text { Number of sample plots with a sighting of a species }} \times \text { Sample plot area }}{\sum\left[\frac{\text { Number of individuals of a species }}{\text { Number of sample plots with a sighting of a species }]}\right.} \times 100
\end{aligned}
$$

$$
\text { Relative Abundance }=\text { Relative Frequency }+ \text { Relative Density }
$$

\section{Importance Value Index (IVI)}

A measure often used to describe and compare the species dominance of the plots is the Importance Value Index of Cottam and Curtis (1956). The IVI for a species is calculated as the sum of its relative dominance, its relative frequency and its relative density. Certain points have to be acknowledged, to understand the arguments the IVI is providing. Also some species may be dominant in one site but do not occur in the other sites. Therefore their local dominance is not displayed in the overall statistics. Still, the IVI is giving a figure with the overall importance of a species.

$$
\begin{aligned}
& \text { Relative Frequency } 2=\frac{\text { Number of individuals of a species }}{\text { Total number of Species }} \times 100 \\
& \text { Relative Dominance } 2=\frac{\text { Total basal area of a species }}{\text { Total basal area for all species }} \times 100 \\
& \text { Relative Density } 2=\frac{\text { Number of individuals of a species }}{\text { Total number of individuals }} \times 100
\end{aligned}
$$$$
\text { IVI = Relative Frequency } 2+\text { Relative Dominance } 2+\text { Relative Density } 2
$$ 


\section{Results and Discussion}

A total of 1335 trees and 4603 herbs were recorded in $11000 \mathrm{~m}^{2}(1.1 \mathrm{ha})$ in six peripheral villages (55 home gardens) in Dumbara region. Hundred and fifty two plant species (19 Endemic species, 44 Naturalized exotics, 37 species - only under cultivation and 52 timber species) under 54 families and 56 herb species (46 Medicinal) belonging to 33 families were recorded.

Euphorbiaceae was the dominant family having 15 species, followed by Fabaceae (11 species), Anacardiaceae (10 species), Rutaceae (10 species), Myrtaceae ( 7 species), Rubiaceae (6 species), Arecaceae (6 species), Moraceae (5 species), Sapindaceae (4 species) and Zingiberaceae (4 species). The remaining families contained 1 to 3 species.

Anacardiaceae, Arecaceae, Cariaceae, Commelinaceae, Euphorbiaceae, Fabaceae, Lauraceae, Meliaceae, Moraceae, Moringaceae, Musaceae, Rubiaceae, Rutaceae, Sabiaceae, Sapindaceae and Sterculiaceae were present in all villages. Highest number of plant families (43) was recorded in Pitawala, while the lowest number of plant families was recorded in Polommana (Table 1). Asteraceae, Boraginaceae, Ebanaceae, Malvaceae, Punicaceae, Theaceae and Thymelaceae were only recorded in Rathninda sites. Plant species in Debrageaceae, Lecythidaceae and Melastomataceae were recorded only in Pitawala home gardens.

Table 1: Number of plant families in each study site

\begin{tabular}{lr}
\hline Village & No. of Plant Families \\
\hline Pitawala & 43 \\
Polommana & 24 \\
Atanwala & 26 \\
Rathninda & 42 \\
Mahala Kotuwa & 34 \\
Illukkumbura & 31 \\
\hline
\end{tabular}

\subsection{Endemic plants, naturalized exotics and timber trees in the study area}

Among the 152 plant species, 19 were endemics (12.5\%). There were 5 endemic plant species; Campnosperma zeylanicum, Mangifera zeylanica, Semecarpus coriaceae, Semecarpus nigro-viridis, Semecarpus walkeri in Family Anacardiaceae. Other endemic species were Callophyllum trapezifolium, Garcinia quaesita (Clusiaceae); Diptocarpus zeylanicus, Shorea hulanidda (Dipterocarpaceae); Agrostistachys hookeri, Phyllanthus myrtifolius (Euphorbiaceae); Aidia gardneri, Diplospera erythrospora (Rubiaceae); Strobilanthes anceps (Acanthaceae); Canarium zeylanicum (Burseraceae); Diospyros oppositifolia (Ebanaceae); Scolopia crassipes (Flacourtiaceae) and Pandanus ceylanicus (Pandanaceae).

Out of the forty four naturalized exotics (28.9\%) found, 5 species name;ly Codiaeum variegatum, Jatropha curcas, Manihot esculenta, Phyllanthus acidus and Ricinus communis were in family Euphorbiaceae. There were 4 from each Fabaceae and Rutaceae. Several other families contained 1 to 3 naturalized exotics. These species are utilized by the home gardeners for various purposes such as fruit, timber, medicine and as fence trees.

Thirty seven species $(23.0 \%)$ out of which 5 species were in family Rutaceae were found only under cultivation in these six villages. Fifty two species $(34.2 \%)$ recorded are used for timber purposes. They are in Combretaceae and Sapindaceae. The major threat is that most endemic plant species such as Campnosperma ceylanicum, Mangifera zeylanica, Garcinia quaesita, Diptocarpus zeylanicus, Shorea hulanidda, Diospyros oppositifolia and Gardonia speciosa are fell for timber. 
3.2. Comparison of endemic species, naturalized exotics and trees only under cultivation in each village

Most of the endemic species (17), naturalized exotic species (44), species found only under cultivation (33) were recorded in Rathninda when comparing with other villages. The lowest number of Endemics (6) was recorded in Atanwala (Figure 2). The number of plant families and the number of plant species recorded in Polommana were comparatively low. This may be because there were only 5 home gardens for the entire village. Other families had left this village in 10 to 15 years ago due to poor access to the home and lack of various other facilities. Therefore, those home gardens (without the home) are now added to the forest boundary and controlled by the forest department. Highest number of plant species was recorded in Rathninda while the lowest number of plant species in Polommana (Figure 2).

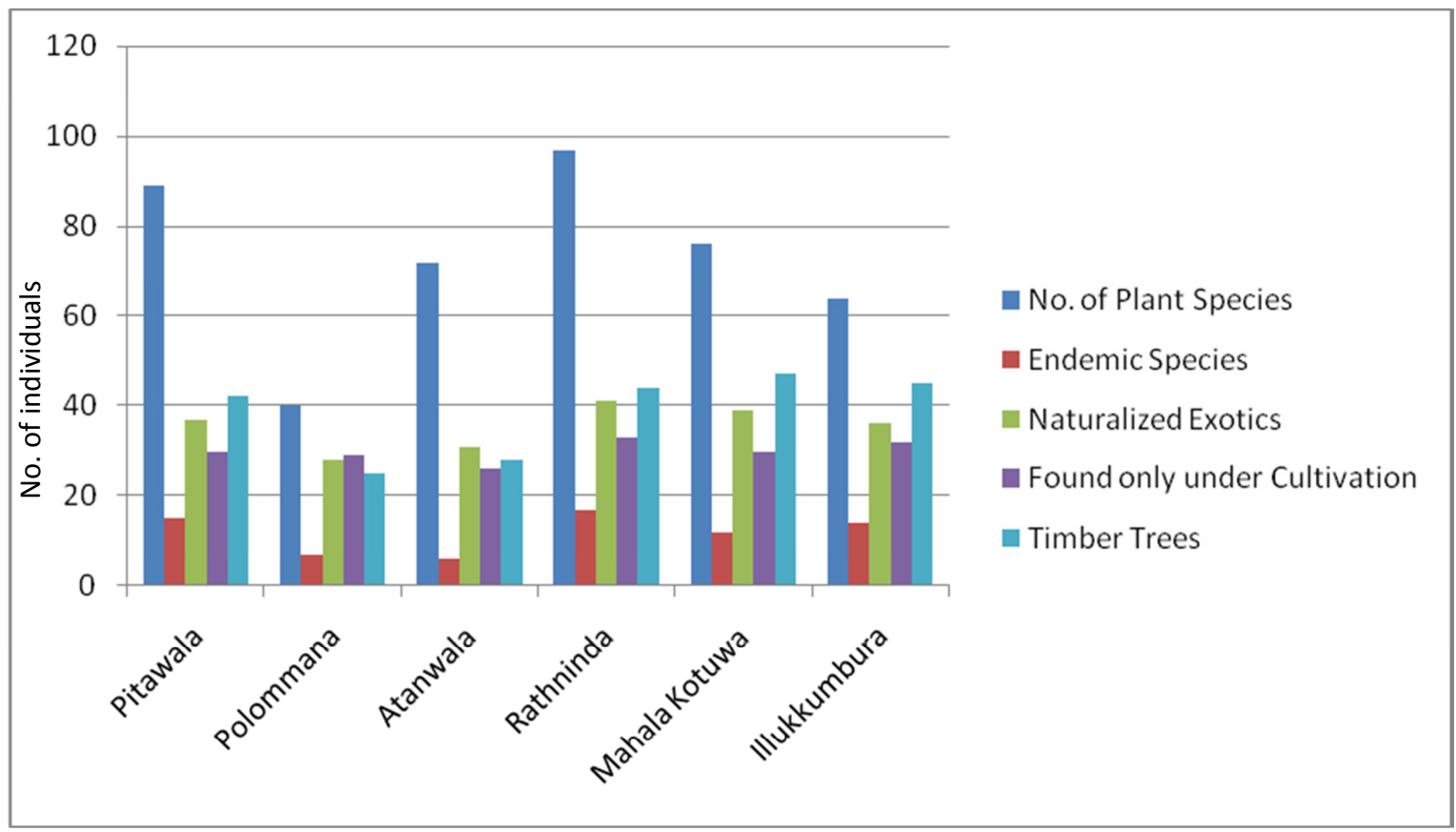

Figure 2: Number of plant species, endemic, naturalized exotic and timber plant species in studied villages

\subsection{DBH Variations of plants in study sites}

All villages are rich with the plants in lowest DBH range $(1-50 \mathrm{~cm})$. Individuals in this range in all villages, are more than twice in number, to the 50-100 cm DBH range (Figure3). Plants in 151-200 $\mathrm{cm}$ DBH range were not observed in Polommana and Atanwala (Figure.3). This may be due to the fact that villagers have used the trees with higher DBH for their timber purposes. Moreover, it should be noted that the DBH also vary depending on the plant species.

Highest number of plant individuals (9 individuals) in both 101-150 cm DBH and $151-200 \mathrm{~cm}$ DBH (7 individuals) was recorded in Pitawala. There were more than two hundred plant individuals in Rathninda and Mahala kotuwa belonging to 1-50 cm DBH range (Figure 3).

\subsection{Height Variation of the plant individuals in the study area}

Most of the plants in studied villages were less than $10 \mathrm{~m}$ in height. There were 21 individuals in 11-15 $\mathrm{m}$ range in Pitawala. Individuals taller than $15 \mathrm{~m}$ were not observed in Polommana and Rathninda (Figure 4). 


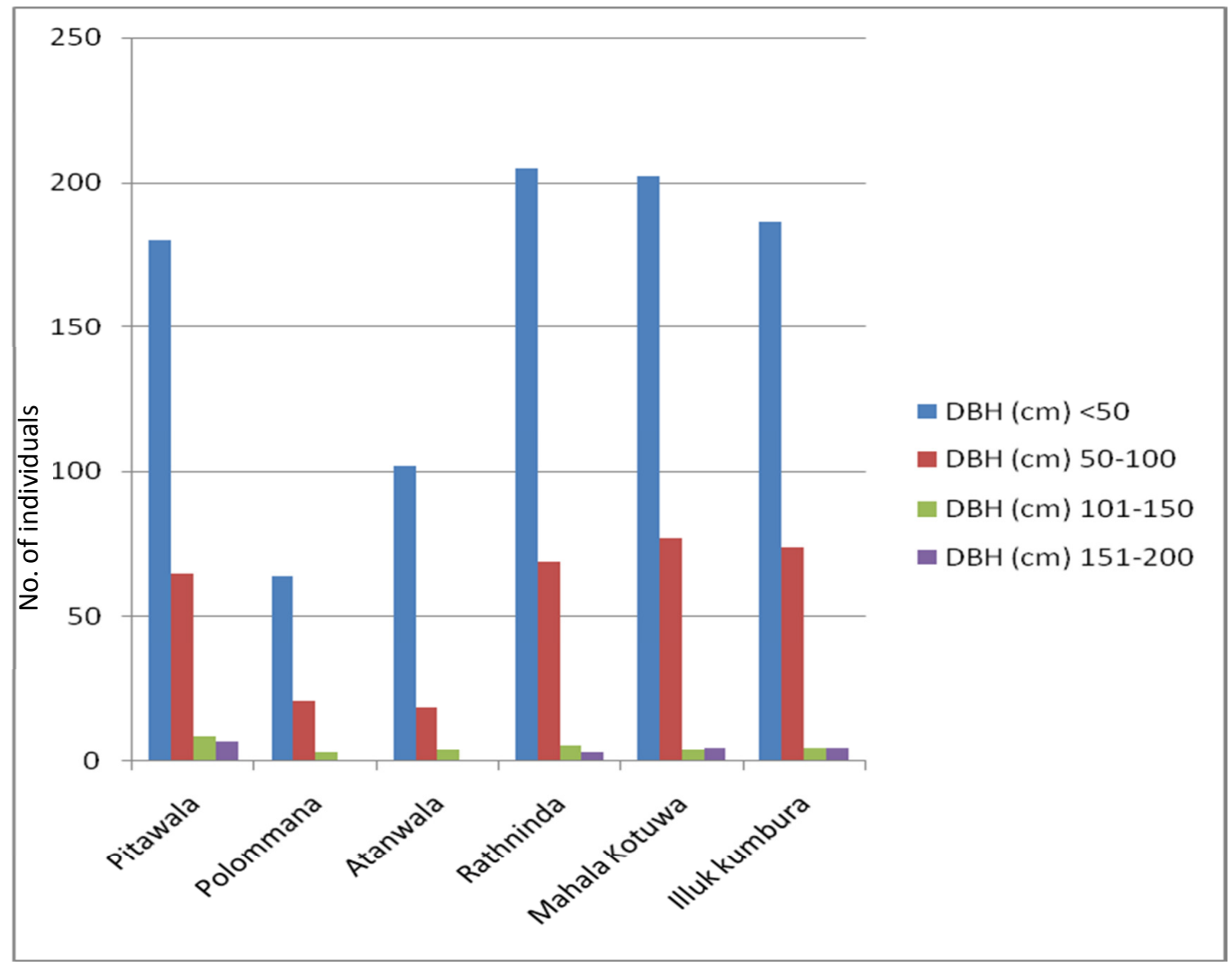

Figure 3: Number of individual plants in each DBH class in all village

\subsection{Density}

The total tree density of Pitawala, Polommana, Atanwala, Rathninda, Mahalakotuwa and Illukkumbura were 1195, 870, 1160, 1310, 1410 and $1240 \mathrm{ha}^{-1}$ respectively. Species were classified into 5 density classes, $\mathrm{E}$ to A; where species that belongs to class $\mathrm{E}$ have lowest density while those in A have highest density. The intermediates were also assigned accordingly. Species that belonged to density class $E$ need more attention with respect to conservation.

Acronychia pedunculata, Adenanthera pavonina, Annona muricata, Bambusa vulgaris, Callophyllum trapezifolium, Capparis zeylanica, Clausena dentata, Semecarpus coriaceae, Shorea hulanidda and Terminalia bellirica in Pitawala; Azadirachta indica, Chrysophyllum lanceolatum, Ficus benghalensis, Melia azedarach and Syzygium malaccensis in Polommana; Ardisia missionis, Cordia aubletii, Madhuca longifolia, Mangifera zeylanica and Trema orientalis in Atanwala; Anacardium occidentale, Campnosperma ceylanicum, Capparis zeylanica, Diospyros oppositifolia and Terminalia chebula in Rathninda; Asystasia variabills, Berrya cordifolia, Nephelium lappaceum, Phyllanthus acidus, Schleichera oleosa and Terminalia bellirica in Mahala Kotuwa; Azadirachta indica, Codiaeum variegatum, Ficus benghalensis, Jatropha curcas, Munronia pinnata, Pandanus ceylanicus, Semecarpus nigro-viridis and Terminalia arjuna in Illukkumbura were in density class E (5-10 density $\left.\mathrm{ha}^{-1}\right)$. On the other hand abundant species in the villages were Artocarpus heterophyllus, Coffea Arabica, Gliricidia sepium, Mangifera indica in Pitawala; Meliosma pinnata, Cocos nucifera in Polommana; Dimocarpus longan, Gliricidia sepium in Atanwala; Pavetta indica, Gliricidia sepium in Rathninda, Tectona grandis in Mahalakotuwa, Artocarpus heterophyllus and Mangifera indica in Illukkumbura.

One species in Mahalakotuwa home gardens Tectona grandis belonged to frequency class A (81-100\%). However species belonging to frequency class B (61-80\%) were absent in those villages. Mangifera indica, Gliricidia sepium in Pitawala; Cocos nucifera, Meliosma pinnata, Cinnamomum verum in Polommana; Areca catechu, Dimocarpus longan, Gliricidia sepium, Pavetta indica in 
Atanwala; Pavetta indica, Gliricidia sepium, Cocos nucifera in Rathninda; Pavetta indica, Gliricidia sepium, Dimocarpus longan, Cocos nucifera, Citrus sinensis in Mahalakotuwa; Tectona grandis, Mangifera indica, Gliricidia sepium, Artocarpus heterophyllus in Illukkumbura belonged to frequency class $\mathrm{C}(41-60 \%)$.

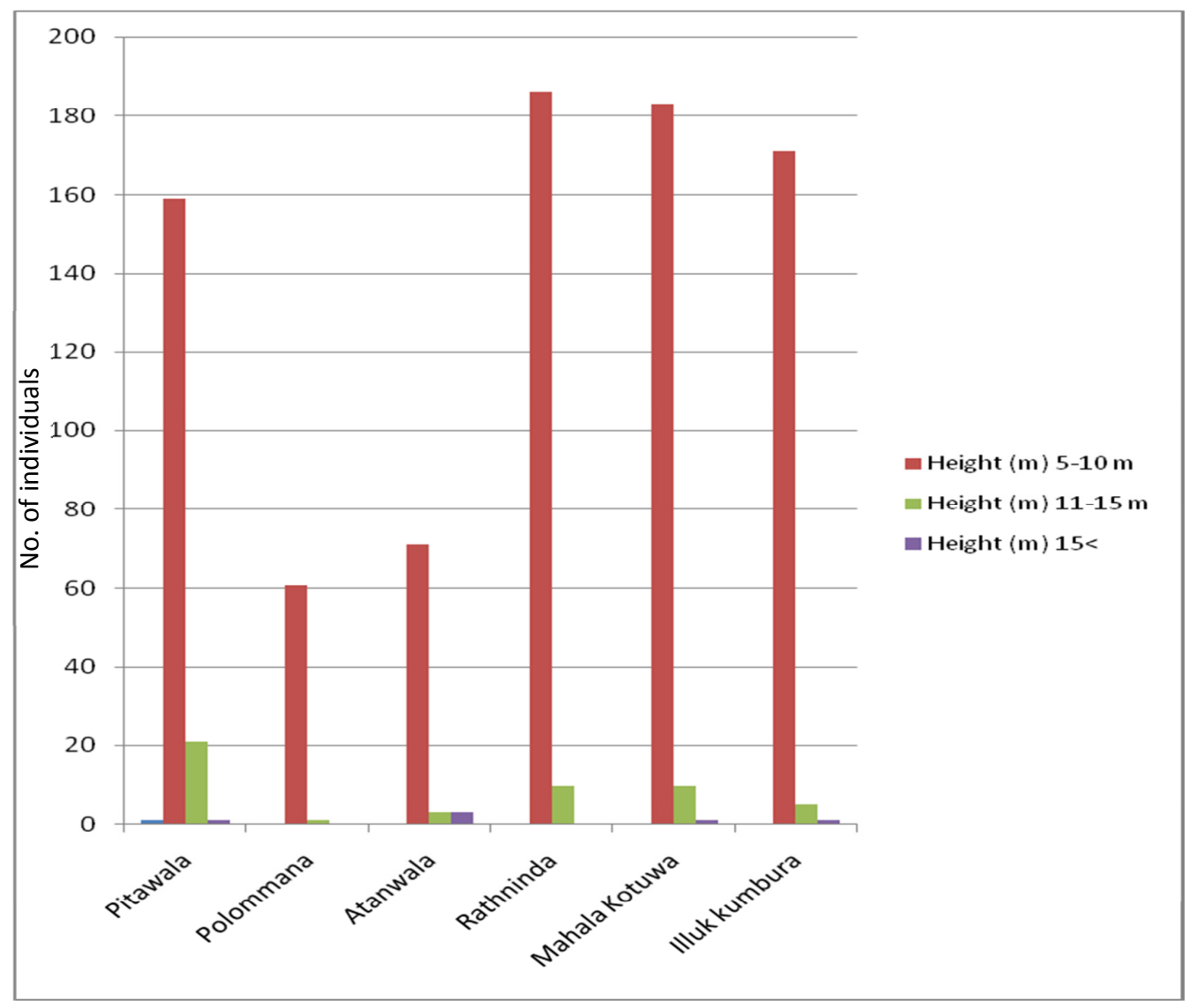

Figure 4: Number of individuals in each height class

The frequency gives an approximate indication of the homogeneity of a stand. Previous studies have pointed out that high values in higher frequency classes (Frequency classes A and B in this case) and low values in lower frequency classes indicate constant or similar species composition while high values in lower frequency classes and low values in higher frequency classes on the other hand indicate a high degree of floristic heterogeneity(give reference). In the present study, high values were obtained in lower frequency classes whereas low values were obtained in higher frequency classes. Therefore, according to the above interpretation, it is possible to conclude that there exists a high degree of floristic heterogeneity in each village in the study area.

\subsection{Basal Area and Dominance}

Total basal areas in Pitawala, Polommana, Atanwala, Rathninda, Mahalakotuwa and Illukkumbura were about 16226.04, 7961.07, 13189.89, 12159.55, 10255.18 and $7647.13 \mathrm{~cm}^{2} \mathrm{ha}^{-1}$, respectively. The highest basal area was recorded in fewer large size individuals; DBH $162 \mathrm{~cm}$ (Artocarpus heterophyllus), $145 \mathrm{~cm}$ (Mangifera indica), $122 \mathrm{~cm}$ (Mangifera zeylanica) in Pitawala; $158 \mathrm{~cm}$ (Artocarpus heterophyllus), $149 \mathrm{~cm}$ (Mangifera indica) in Polommana; 158 (Ficus hispida), $132 \mathrm{~cm}$ (Mangifera indica) in Atanwala; $128 \mathrm{~cm}$ (Artocarpus heterophyllus), $105 \mathrm{~cm}$ (Artocarpus nobilis) in Rathninda; $108 \mathrm{~cm}$ (Artocarpus heterophyllus) in Mahalakotuwa and $89 \mathrm{~cm}$ (Terminalia arjuna) in Illukkumbura. The highest contribution to their total basal area was by those individual trees that attain greater than $100 \mathrm{~cm}$ DBH for many species. 
Basal area provides a better measure of the relative importance of the species than simple stem count (Cain and Castro 1959, cited in Tamirat Bekele, 1994). Therefore, species with the largest contribution in basal area can be considered as the most important woody species in the forest. High density and high frequency indicates regular horizontal distribution in the forest. High density, low frequency and low dominance are typical for understory species that occur in clusters. Some tree species with low density, low frequency and low dominance are the threaten species in the area.

\subsection{Importance Value Index}

To analyse IVI, all species encountered in all villages were grouped into five IVI classes based on their total IVI values. Those species, which receive lowest IVI value, were grouped into the fifth IVI class whereas those species with highest IVI value were put under the first IVI class. Those species, which were grouped in the fifth IVI class needs highest consideration for conservation while those grouped in the first IVI class, need monitoring and management.

Based on the IVI output, the following species accorded the highest priority for conservation efforts: Osbeckia aspera (1.02), Acronychia pedunculata (1.12), Murraya exotica (1.16), Bambusa vulgaris(1.20), Clausena dentata(1.25)in Pitawala; Phyllanthus indicus (2.66), Manihot esculenta (2.66), Bambusa vulgaris (2.84), Annona glabra(3.05), Moringa oleifera(3.14) in Polommana; Alstonia scholaris (1.07), Citrus grandis (1.21), Melia azedarach(1.29), Cordia monocica (1.42), Syzygium assimile (1.42) in Atanwala. Hibiscus rosa-sinensis (0.86), Phyllanthus reticulates (0.87), Manihot esculenta(0.90), Melia azedarach(0.93) in Rathninda; Solanum violaceum Ortega (0.95), Phyllanthus emblica (0.97), Phyllanthus acidus (0.99), Citrus reticulate (1.02), Bambusa vulgaris (1.05) in Mahala Kotuwa; Pandanus ceylanicus (1.11), Anacardium occidentale (1.18), Phyllanthus emblica (1.25), Codiaeum variegatum (1.72), Flacourtia indica (1.72) in Illukkumbura.

The importance value index is imperative to compare the ecological significance of species (Lamprecht, 1989). It indicates the extent of dominance of a species in the structure of a forest stand (Curtis and McIntosh, 1951). It is stated that species with the greatest importance value are the leading dominants of the forest.

\subsection{Diversity Indices}

If Shannon diversity index value lies between 1.5 and 3.5 , it is considered as a less disturbed habitat. When this index value reaches 3.5, the habitat is more stable. According to the Shannon diversity values of these study sites; Rathninda (1.85) is the most stable less disturbed habitat when compared with the others. Polommana (1.51) seemed to be the most disturbed and unstable habitat (Table 2).

The increased value for Margalef diversity indicates the high Biodiversity. This is a comparative measure with other sites. In this case Pitawala (16.069) has the highest diversity while Polommana (8.733) has the lowest (Table 2). If Simpson Biodiversity index is less than 0.5; species are more equitable. Here all the values are around 1.0, and hence species are heterogeneous.

\subsection{Composition of herbs in the study area}

Fabaceae was the leading family for herbs including seven plant species. Asteraceae and Poaceae contained four species in each, in Rubiaceae there were 3 species. Remaining families contained 1 to 2 species (Appendix I). Lamiaceae is the dominating plant family in the study area counting 797 individuals. Nevertheless there were only two species in this family, Ocimum tenuiflorum and Plectranthus zatarhendi (Appendix I). In number; 2588 plant individuals were found in Pitawala (56.22\% of total individuals); all the recorded families except Anacardiaceae and Menispermaceae were present in Pitawala (93.93\%). 
Table 2: Diversity indices for plant species (excluding herbs) in all study sites

\begin{tabular}{|c|c|c|c|c|c|c|c|c|c|c|c|}
\hline \multirow{2}{*}{ Village } & \multirow{2}{*}{$\begin{array}{l}\text { No. of } \\
\text { species }\end{array}$} & \multirow{2}{*}{$\begin{array}{l}\text { No. of } \\
\text { individu } \\
\text { als }\end{array}$} & \multirow{2}{*}{$\begin{array}{l}\text { Margalef } \\
\text { Diversity }\end{array}$} & \multirow{2}{*}{$\begin{array}{l}\text { Menhink } \\
\text { Diversity }\end{array}$} & \multicolumn{2}{|c|}{$\begin{array}{l}\text { Shannon } \\
\text { diversity }\end{array}$} & \multicolumn{2}{|c|}{$\begin{array}{l}\text { Brillouin } \\
\text { Diversity }\end{array}$} & \multicolumn{3}{|c|}{ Evenness } \\
\hline & & & & & $\begin{array}{c}\text { Base } \\
10\end{array}$ & Base 2 & $\begin{array}{c}\text { Base } \\
10\end{array}$ & $\begin{array}{c}\text { Base } \\
2\end{array}$ & $\begin{array}{l}\text { Simpson } \\
\text { Diversity }\end{array}$ & $\begin{array}{c}\text { Inverse } \\
\text { Simpson } \\
\text { dominance }\end{array}$ & $\begin{array}{l}\text { Shannon } \\
\text { Diversity }\end{array}$ \\
\hline Pitawala & 25 & 578 & 3.774 & 1.04 & 1.26 & 4.18 & 1.22 & 4.05 & 0.972 & 0.591 & 0.901 \\
\hline $\begin{array}{l}\text { Polom- } \\
\text { mana }\end{array}$ & 23 & 318 & 3.818 & 1.29 & 1.19 & 3.94 & 1.13 & 3.74 & 0.956 & 0.487 & 0.87 \\
\hline Atanwala & 21 & 381 & 3.365 & 1.08 & 1.04 & 3.31 & 1 & 3.31 & 0.896 & 0.312 & 0.789 \\
\hline Rathninda & 31 & 560 & 4.741 & 1.31 & 1.33 & 4.41 & 1.28 & 4.24 & 0.971 & 0.518 & 0.889 \\
\hline $\begin{array}{l}\text { Mahala } \\
\text { Kotuwa }\end{array}$ & 29 & 427 & 4.623 & 1.40 & 1.32 & 4.4 & 1.27 & 4.21 & 0.979 & 0.618 & 0.905 \\
\hline $\begin{array}{l}\text { Illuk- } \\
\text { kumbura }\end{array}$ & 22 & 356 & 3.575 & 1.17 & 1.2 & 3.99 & 1.15 & 3.82 & 0.965 & 0.559 & 0.895 \\
\hline
\end{tabular}

A Shannon index for any of the village does not lie between the ranges of $1.5-3.5$. So, herbaceous layer in each study site is disturbed and less stable. Margalef diversity value is higher in Rathninda village (4.741), followed by Mahalakotuwa (4.623). Less diversity of the herb species in ground layer is shown in Atanwala. Simpson diversity values in all villages are more than 0.5 . As such, species in all villages are heterogeneous (Table 3 ).

Table 3. Diversity indices for herbaceous layer in each study site

\begin{tabular}{|c|c|c|c|c|c|c|c|c|c|}
\hline \multirow{2}{*}{ Village } & \multirow{2}{*}{$\begin{array}{c}\text { No. of } \\
\text { species }\end{array}$} & \multirow{2}{*}{$\begin{array}{c}\text { No. of } \\
\text { individuals }\end{array}$} & \multirow{2}{*}{$\begin{array}{l}\text { Margalef } \\
\text { Diversity }\end{array}$} & \multirow{2}{*}{$\begin{array}{l}\text { Menhink } \\
\text { Diversity }\end{array}$} & \multicolumn{2}{|c|}{$\begin{array}{l}\text { Shannon } \\
\text { diversity }\end{array}$} & \multicolumn{3}{|c|}{ Evenness } \\
\hline & & & & & Base 10 & $\begin{array}{c}\text { Base } \\
2\end{array}$ & $\begin{array}{l}\text { Simpson } \\
\text { Diversity }\end{array}$ & $\begin{array}{c}\text { Inverse } \\
\text { Simpson } \\
\text { dominance }\end{array}$ & $\begin{array}{l}\text { Shannon } \\
\text { Diversity }\end{array}$ \\
\hline Pitawala & 89 & 239 & 16.069 & 5.757 & 1.79 & 5.93 & 0.988 & 0.366 & 0.916 \\
\hline Polommana & 40 & 87 & 8.733 & 4.288 & 1.51 & 5 & 0.987 & 0.516 & 0.94 \\
\hline Atanwala & 72 & 230 & 13.056 & 4.748 & 1.71 & 5.69 & 0.988 & 0.443 & 0.922 \\
\hline Rathninda & 97 & 259 & 17.276 & 6.027 & 1.85 & 6.13 & 0.992 & 0.439 & 0.929 \\
\hline Mahala Kotuwa & 76 & 272 & 13.379 & 4.608 & 1.71 & 5.69 & 0.988 & 0.45 & 0.911 \\
\hline Illuk-kumbura & 64 & 248 & 11.427 & 4.064 & 1.66 & 5.52 & 0.987 & 0.475 & 0.92 \\
\hline
\end{tabular}

\subsection{Villagers' income through their home garden products}

People in Polommana receive higher income through their home garden because they have no other option to increase their economy other than cultivating crops. Though they are far away from accessible facilities they grow crops in large areas to have their income. There was no statistically significant relationship between the level of economy and the composition of plant species in the home garden (chi-square $=13.308^{\mathrm{a}}, \mathrm{p}=0.102$ ).

\subsection{Expected other plants}

Preference of villagers regarding what to grow in their home gardens varies from family to family. Most prefer Cocos nucifera (57\%) due to increasing price of coconut. Twenty four percent of people expressed an interest in growing timber trees as Tectona grandis, Melia azedarach, Swietenia macrophylla and Chloroxylon swietenia. Twelve percent preferred fruit trees, 5\% requested for medicinal plants such as Azadirachta indica, Munronia pinnat and Cannabis sativa. These expectations indicate that in the near future, only few plant species will be grown in these home 
gardens (Figure 5). Consequently, the biodiversity will be greatly reduced and might even lead to the extinction of rare, endangered species.

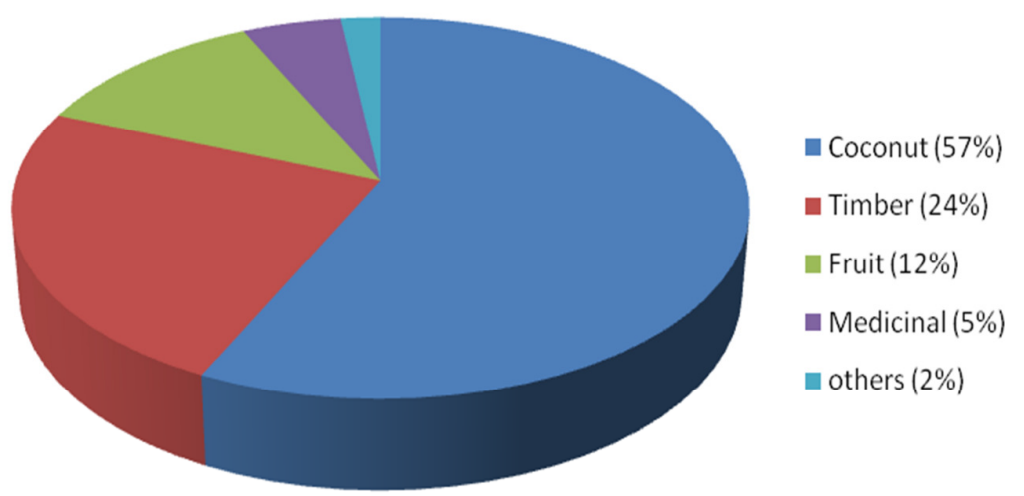

Figure 5. Preference of home gardeners for various categories of plants

\subsection{Plant diseases and home garden management}

Plant diseases such as fungal attacks in bark, insect attacks in coconut bark, Iron deficiencies, harms of vegetable caterpillar, insect damages in leaves and parasitic plants were observed in home gardens. Plant management can be different in each home garden and the amount of planting in a garden is often difficult to evaluate. Plant management in home gardens was categorized into three main groups: cultivated, protected or spared.

1. When plants are said to be cultivated, they are sown or planted by the owner.

2. Plants are categorised as protected or encouraged when they are transplanted from other zones outside the garden or when they grow spontaneously in the garden. The owner decides to protect or encourage the plant, for example, by supporting it or attaching the plant to a solid structure, or by putting stones around the plant.

3. Spared plants are plants that spontaneously grow in the garden and are not removed. Either the farmer knows that the plant does not harm any other plant in the garden, or that it has a specific use. Also trees for shade or the edible species are spared. These plants belonged to the original vegetation before the farmers settled in and were not removed when the house was built or when the home garden was established.

3.13 Villagers' attitudes and contribution towards the Biodiversity Conservation through their Home garden

Seventy two percent of people in all villages knew that by improving the plant composition in their home garden, they can contribute to protect the biodiversity. They were aware of the fact that the richness of plant composition in home garden will lead to the improvement of human beings as well as the protection of the Dumbara forest. However the important thing to be pointed out is that $23 \%$ of people didn't know that they can conserve biodiversity through the home gardens. So to have a better world in the future, for their children and for future generations, they should be encouraged to conserve biodiversity in their home. Another point is that if the biodiversity is maintained at a high level, species extinction will be low. This will benefit everyone.

The majority of the people were aware that the conservation can be done not only in the forests but also in their home gardens. To conserve the biodiversity, women have started to plant various wild varieties of crops in their home gardens. Women can be encouraged to grow a variety of species to obtain cut flowers. They can make an income out of it. 
People of the bordering villages are well aware of the importance of the Dumbara forest. So, they inform relevant authorities if a stranger tries to enter into the forest. They don't complain about the people that go to get medicine and poles to make utensils. According to females of the bordering villages, they do not cut down trees or kill animals, not only in the forest but also in their home gardens. Educating people, mainly the younger generation about the importance of the biodiversity and the Dumbara is done mainly by the females/mothers. They fulfil the task by giving the traditional knowledge and the cultural values to the future generations.

The isolation of the region, its frontier character, and the rapid changes that are occurring, in terms of population growth, legal state of land, and political boundaries, make socio-economic data scares and unreliable. The clandestine nature of many activities in the area and the uncertain legality of others make it difficult to get honest responses from local people or government officials about local activities.

Biodiversity loss of the Dumbara forest is resulting due to at least two proximate causes: the habitat loss and the extraction of flora and fauna. The direct or indirect cause for the habitat fragmentation in the Dumbara forest was clearing for agriculture in the past. Poverty is prominent in the bordering villages of Dumbara forest.

Cash is earned by selling agricultural products which provides the main source of income for the bordering villagers and from day labour. Agriculture, in the study area remains small-scale as a result of ecological limitations such as shortage of water during the year and unpredicted weather patterns as well as economical limitations such as lack of proper market value. Due to the increasing population, encroachment can be seen. Hunting is another threat to the biodiversity of Dumbara forest. Hunting is carried out by man in the farm plots to protect their crops from wild boars and spotted deer. Even though the hunting is illegal these people have no other option.

According to gathered information giant-squirrels have become a menace to the people of the bordering villages. This species destroy the crops of the home gardens. This is a great economic loss but still a solution has not been provided by the government.

\section{Conclusions}

Home gardens in Dumbara Conservation area comprises with high number of endemic species, timber species, and naturalized exotics with cultivated crops. People in these peripheral villages have no proper idea as how to attain plant conservation through the home gardens. Awareness programs can direct villagers to obtain the maximum benefit of the home garden rather than going into the forest for extractable products. Traditional knowledge of the fringe villagers should also be conserved.

\section{References}

Acar, C., Acar, H. And Eroglu, E. (2007). Evaluation of ornamental plant resources to urban biodiversity and cultural changing: A case study of residential landscapes in Trabzon city (Turkey). Building and Environment, 42(1): 218-229.

Albuquerque, U.P, Andrade, L.H.C. and Caballero, J. (2005). Structure and floristic of home gardens in Northeastern Brazil. Journal of Arid Environments, 62(3): 491-506.

Blanckaert, I., Swennen, R., Paredes-Flores, M., Rosas-López, R. and Lira, R. (2004). Floristic Composition, Plant Uses and Management Practices in Home Gardens of San Rafael Coxcatlan, Puebla, Mexico. Journal of Arid Environments, 57: 39-62.

Hochegger, K. (1998). Farming like the forest: Traditional home garden systems in Sri Lanka. Margraf, Weikersheim, Germany: 203 pp.

Kehlenbeck, K, Maass, B.L. (2004). Crop diversity and classification of home gardens in Central Sulawesi, Indonesia. Agroforestry Systems, 63: 53-62.

McConnell, D.J. (2003). The forest farms of Kandy and other gardens of complete design. Ashgate

Publishing, Ltd.: 535 pp. 
Pandey, C.B., Lata, K., Venkatesh, A. and Medhi, R.P. (2006). Diversity and species structure of home gardens in South Andaman. Tropical Ecology, 47(2): 251-258.

Pandey, C.B., Rai, R.B., Singh, L. and Singh, A.K. (2007). Home gardens of Andaman and Nicobar, India. Agricultural Systems, 92(1-3): 1-22.

Tynsong, H. and Tiwari, B.K. (2010). Plant Diversity in the Home gardens and their Significance in the Livelihoods of War Khasi Community of Meghalaya, North-east India. Journal of Biodiversity, 1(1): 1-11.

Richards, P.W., (1952). The tropical rain forest. Cambridge University Press, Cambridge.

\section{Appendix I:}

Total number of trees/ shrubs belonging to different families in each village

\begin{tabular}{|c|c|c|c|c|c|c|}
\hline Plant Family & Pitawala & Polommana & Atanwala & Ratninda & $\begin{array}{l}\text { Mahala } \\
\text { kotuwa }\end{array}$ & Illukkumbura \\
\hline ACANTHACEAE & 8 & 0 & 0 & 0 & 0 & 4 \\
\hline ALOACEAE & 46 & 5 & 5 & 6 & 17 & 0 \\
\hline AMARANTHACEAE & 136 & 42 & 8 & 0 & 21 & 24 \\
\hline ANACARDIACEAE & 0 & 3 & 0 & 0 & 0 & 0 \\
\hline APIACEAE & 270 & 46 & 52 & 62 & 27 & 31 \\
\hline ARACEAE & 0 & 0 & 0 & 5 & 0 & 0 \\
\hline ASPARAGACEAE & 83 & 8 & 0 & 24 & 0 & 23 \\
\hline ASTERACEAE & 174 & 23 & 9 & 8 & 31 & 18 \\
\hline BROMELIACEAE & 3 & 0 & 0 & 0 & 0 & 0 \\
\hline CANNACEAE & 15 & 0 & 0 & 5 & 2 & 4 \\
\hline COMMELINACEAE & 3 & 0 & 0 & 0 & 3 & 0 \\
\hline CONVOLVULACEAE & 33 & 2 & 0 & 31 & 0 & 0 \\
\hline CRASSULACEAE & 3 & 0 & 0 & 0 & 0 & 3 \\
\hline CUCURBITACEAE & 73 & 12 & 7 & 13 & 5 & 12 \\
\hline EUPHORBIACEAE & 14 & 0 & 0 & 0 & 1 & 13 \\
\hline FABACEAE & 198 & 20 & 19 & 22 & 59 & 37 \\
\hline LAMIACEAE & 431 & 47 & 122 & 98 & 37 & 62 \\
\hline MALVACEAE & 142 & 7 & 17 & 35 & 23 & 24 \\
\hline MELASTOMATACEAE & 3 & 3 & 00 & 0 & 0 & 0 \\
\hline MELIACEAE & 23 & 0 & 4 & 7 & 5 & 0 \\
\hline MENISPERMACEAE & 0 & 0 & 3 & 2 & 0 & 0 \\
\hline PANDANACEAE & 71 & 4 & 19 & 8 & 11 & 13 \\
\hline PHTOSPORACEA E & 23 & 0 & 0 & 13 & 10 & 0 \\
\hline PLUMBAGINACEAE & 12 & 0 & 0 & 9 & 3 & 0 \\
\hline POACEAE & 169 & 26 & 25 & 32 & 46 & 14 \\
\hline RUBIACEAE & 79 & 0 & 0 & 55 & 2 & 12 \\
\hline RUTACEAE & 134 & 26 & 21 & 17 & 21 & 13 \\
\hline SAPINDACEAE & 162 & 20 & 7 & 42 & 29 & 31 \\
\hline SMILACACEAE & 4 & 0 & 0 & 4 & 0 & 0 \\
\hline SOLANACEAE & 2 & 0 & 0 & 0 & 0 & 0 \\
\hline TILLIACEAE & 2 & 0 & 0 & 0 & 2 & 0 \\
\hline TRAPACEAE & 47 & 6 & 6 & 14 & 3 & 3 \\
\hline ZINGIBERACEAE & 225 & 18 & 57 & 48 & 42 & 15 \\
\hline
\end{tabular}

